\title{
Differential sensitivity of breast cancer and melanoma cells to proteasome inhibitor Velcade
}

\author{
AZMI YERLIKAYA ${ }^{1}$ and NURAY ERIN ${ }^{2}$ \\ ${ }^{1}$ Dumlupinar University, Art and Science Faculty, Department of Biology, Kütahya; \\ ${ }^{2}$ Akdeniz University, College of Medicine, Department of Internal Medicine, Antalya, Turkey
}

Received July 11,2008; Accepted August 25, 2008

DOI: 10.3892/ijmm_00000090

\begin{abstract}
Velcade (also known as PS-341 or Bortezomib) is a highly selective and reversible inhibitor of the $26 \mathrm{~S}$ proteasome and is approved for the treatment of patients with advanced multiple myeloma. Here we investigated the antiproliferative effect of Velcade on 4T1 breast cancer and B16F10 melanoma cells and evaluated the mechanism of action. It was found that two cell lines are differentially sensitive to proteasome inhibitor Velcade. The $\mathrm{IC}_{50}$ concentrations for B16F10 and 4T1 were $2.5 \mathrm{nM}$ and $71 \mathrm{nM}$, respectively, indicating that $\mathrm{B} 16 \mathrm{~F} 10$ cells are more sensitive to proteasomal inhibition. Velcade was equally potent in inhibiting the chymotrypsin-like activity of the proteasome in both cell lines. It was determined that B 16 F 10 cells proliferate more rapidly than $4 \mathrm{~T} 1$ cells; doubling time $\left(T_{d}\right)=$ $14.2 \mathrm{~h}$ versus $T_{d}=22.9 \mathrm{~h}$, suggesting that a rapid proliferation rate may be an important factor in cellular resistance towards proteasomal inhibition. We observed for the first time that p53 and $\mathrm{p} 21$ proteins were increased in B16F10 cells but not in 4T1 following Velcade-treatment, demonstrating that p53 and p21 may enhance Velcade sensitivity. Furthermore, it was observed that caspase- 3 proenzyme was reduced by $\sim 20 \%$ in B16F10 melanoma cells, but not in 4T1 cells in response to $26 \mathrm{~S}$ proteasomal inhibition by Velcade. Altogether, we concluded that p53 protein plays a central role in higher sensitivity of B16F10 cells to Velcade by
\end{abstract}

Correspondence to: Dr A. Yerlikaya, Dumlupinar University, Art and Science Faculty, Department of Biology, Kütahya, 43100 Turkey

E-mail: ayerlikaya@dumlupinar.edu.tr

Abbreviations: ECL, enhanced chemiluminescence; MTT, [3(4,5-dimethylthylthiazol-2-yl)-2,5-diphenyltetrazolium bromide]; PVDF, polyvinylidene fluoride; DMSO, dimethyl sulfoxide; MG132, carbobenzoxyl-L-leucyl-L-leucyl-L-leucinal; IC $_{50}$, inhibition concentration 50; Hsp, heat shock protein; LLVY-AMC, Leu-Leu-Val-Tyr-7-amino-4-methylcoumarin; RFU, relative fluorescence unit.

Key words: 26S proteasome, cancer, apoptosis, proliferation, Velcade, carbobenzoxyl-L-leucyl-L-leucyl-L-leucinal, p53 inducing the accumulation of $\mathrm{p} 21$, a cell cycle inhibitor, as well as by stimulating the mitochondrial pathway of apoptosis through caspase- 3 activation.

\section{Introduction}

The 26S proteasome, is an intracellular ATP-dependent multicatalytic protease involved in the degradation of shortlived proteins under normal metabolic conditions. It is also involved in the degradation of long-lived proteins, the processing of certain proteins (e.g., transcription factor $\mathrm{NF}-\kappa \mathrm{B})$, and antigen presentation $(1,2)$. The $26 \mathrm{~S}$ proteasome has a molecular mass of $\sim 2.5 \mathrm{MDa}$ and is formed by the assembly of one $20 \mathrm{~S}$ proteasome complex (the core particle) with 2 molecules of the $19 \mathrm{~S}$ complex, the regulatory complex. The 19S regulatory complexes are attached to both ends of the $20 \mathrm{~S}$ proteasome. The eukaryotic $20 \mathrm{~S}$ proteasome is made up of 2 copies of 7 distinct $\alpha$ and 7 distinct $\beta$-type subunits. The $\alpha$ subunits make up the 2 outer layers, and the $B$ subunits the 2 inner rings of the structure [i.e. $\left(\alpha_{1}-\alpha_{7}\right)\left(\beta_{1}-\beta_{7}\right)\left(\beta_{1}-\beta_{7}\right)\left(\alpha_{1}-\alpha_{7}\right)$ ] $(3,4)$.

Studies of the proteasome inhibitors MG132 and lactacystin indicated that the proteasome is responsible for the degradation of $>80 \%$ of intracellular proteins. Among the key regulatory proteins degraded by the $26 \mathrm{~S}$ proteasome are the transcription factor c-Fos, M-, S-, and G1-phase specific cyclins, cyclin-dependent kinase inhibitors, p53, polyamine biosynthetic enzymes ornithine decarboxylase, S-adenosylmethionine decarboxylase, and a variety of oncoproteins $(1,5-8)$. For targeting the $26 \mathrm{~S}$ proteasome, substrate proteins are usually conjugated to a 76 amino acid protein ubiquitin, a multistep process. First, ubiquitin is transferred to the ubiquitin activating enzyme (E1), from there it is transferred to one of the ubiquitin conjugating enzymes (E2). Finally, the ubiquitin molecule is either donated directly to substrate proteins or is transferred to the ubiquitin ligase (E3), which performs the final transfer of the activated ubiquitin to the specific proteins. After the first attachment of the ubiquitin molecule, a polyubiquitin chain is formed on the substrate protein; each additional ubiquitin is linked to the lysine 48 of the previous ubiquitin molecule (9-11).

Proteasome inhibitors exhibit antitumor activities in a number of cancer models by triggering apoptosis. The mechanism of action generally involves inhibition of the 
processing of the proenzyme form of NF- $\mathrm{kB}$ (important for cell survival), and by accumulation of pro-apoptotic proteins Bid, Bax, tumor suppressor p53 and cyclin-dependent kinase inhibitors p21 and p27 (12). Due to their manageable clinical toxicity and significant antitumor activities, they are currently tested in clinical studies. The dipeptide boronic acid analogue Velcade (formerly known as Bortezomib or PS-341) is the first proteasome inhibitor used in clinical trial for the treatment of a number of malignancies, e.g., multiple myeloma, nonHudging lymphoma, non-small cell lung cancer (NSCLC), and other solid tumors (13-15). In contrast to peptide aldehyde inhibitors (e.g., MG132), Velcade is a more potent and selective proteasome inhibitor. This boronic acid inhibitor blocks threonine protease activity by inhibiting the chymotryptic activity of the $26 \mathrm{~S}$ proteasome (16). Although promising results were obtained in several clinical studies, Velcade was not found to be effective as a single agent in the treatment of patients with metastatic melanoma (17). In addition, cotreatment with Velcade did not overcome the resistance of mammary tumor cells to antitumor drugs, such as cyclophosphamide and cisplatine under in vitro conditions (18). Recently, it was demonstrated that resistance to proteasome inhibitor treatment was associated with increased expression of proteasomal subunits in NSCLC cell lines, leukemia and lymphoma cells $(15,19)$. Additionally, upon exposure to proteasome inhibitor, increased resistance to apoptosis may result from the accumulation of anti-apoptotic protein, $\mathrm{Bcl} 2$ family member proteins and Heat shock proteins (20). These studies indicated that the $26 \mathrm{~S}$ proteasome, whose many functions are still unknown, needs to be investigated in detail. In this study, we investigated the growth inhibitory effect of Velcade on 4T1 breast cancer and B16F10 melanoma cells. We observed that both cell lines are differentially sensitive to $26 \mathrm{~S}$ proteasome inhibition by Velcade.

\section{Materials and methods}

Materials. Enhanced chemiluminescence (ECL) detection reagent for Western blotting and Bio-Rad protein assay reagents were purchased from Amersham Pharmaceuticals (now GE, Arlington Heights, IL). RPMI-1640 cell culture media, fetal bovine serum (FBS), trypsin, penicillin/streptomycin, MG132 and Bio-Max X-ray film were obtained from Sigma-Aldrich Inc. (St. Louis, MO). PVDF membrane was from Millipore Inc. Mouse monoclonal anti-Hsp70 antibody was from Sigma-Aldrich Inc. Anti-p27 (BD Bioscience) and anti-p53 antibodies (Novocastra Laboratories) were a kind gift of Dr David J. Feith (Penn State University College of Medicine, Hershey, PA) and anti-p21 antibody (Santa Cruz) was kindly provided by Lisa M. Shantz (Penn State University College of Medicine, Hershey, PA). MTT [3-(4,5dimethylthylthiazol-2-yl)-2,5-diphenyl-tetrazolium bromide] was kindly provided by Dr Diane McCloskey (Penn State University College of Medicine, Hershey, PA). Rabbit polyclonal anti-caspase-3 antibody was purchased from Santa Cruz Biotechnology Inc. 20S proteasome activity assay kit was obtained from Chemicon International. Velcade (PS341) was generously provided by Dr Engin Ulukaya (Uludag University, Bursa, Turkey). All other reagents were purchased from Sigma-Aldrich Inc. unless otherwise mentioned.
Cell culture maintenance. 4T1 and B16F10 cells were maintained in RPMI-1640 (plus $4.5 \mathrm{~g} / 1$ glucose, $10 \mathrm{mM}$ HEPES, $1 \mathrm{mM}$ sodium pyruvate, $0.15 \%$ sodium bicarbonate, $100 \mu \mathrm{g} / \mathrm{ml}$ streptomycin and $100 \mathrm{U} / \mathrm{ml}$ penicillin) supplemented with $10 \%$ FBS. Cells were incubated in a humidified atmosphere at $37^{\circ} \mathrm{C}$ with $5 \% \mathrm{CO}_{2}$. Stock cultures were maintained in $25 \mathrm{~cm}^{2}$ Corning flasks, and experimental cultures were grown in $35 \times 10 \mathrm{~mm}$ Corning plates. The cells were subcultured when they were $70-80 \%$ confluent.

Growth curve. Cells $(100,000)$ were plated in $35 \times 10 \mathrm{~mm}$ dishes. The growth rate of each cell was determined by counting the number of cells using a hemacytometer as a function of time. Using the Prism 3.03 program, data from the exponential phase of growth (data points at 24, 48 and 72 h) were used to obtain an exponential growth curve $\left(N_{t}=N_{o} x\right.$ $e^{K x t}$ ) where $N_{t}$ is the cell number at time $t ; N_{o}$ is the cell number at the initial time, and $K$ is the constant rate. Doubling time $\left(T_{d}\right)$ was then obtained using the formula: $T_{d}=\ln 2 / K$.

MTT-based cytotoxicity assay. Cells $(50,000)$ were seeded in each plate $(35 \times 10 \mathrm{~mm})$. Cells in the exponential phase of the growth were treated with various doses of Velcade $(0.001$, $0.01,0.1,1,10$ or $100 \mu \mathrm{M})$ or MG132 $(0.01,0.1,0.5,1,10$ or $50 \mu \mathrm{M}$ ) for $24 \mathrm{~h}$. After the inhibitor exposure period, cells were fed fresh media. At $48 \mathrm{~h}$ after the inhibitor removal, cells were treated for $4 \mathrm{~h}$ with RPMI-1640 media containing $0.5 \% \mathrm{FBS}+0.5 \mathrm{mg} / \mathrm{ml} \mathrm{MTT}$ at $37^{\circ} \mathrm{C}$ with $5 \% \mathrm{CO}_{2}$ to determine the number of surviving cells. After removing the medium and MTT, cells were incubated with 3\% SDS (200 $\mu \mathrm{l})$ $+1 \mathrm{ml} 40 \mathrm{mM} \mathrm{HCl} /$ isopropanol for $15 \mathrm{~min}$ at room temperature with intermitten shaking to dissolve the MTT-formazan crystals. The homogenate in each plate was pipetted well to dissolve the MTT-formazan crystals completely and centrifuged at $12,000 \mathrm{rpm}$ for $5 \mathrm{~min}$. The absorbance at $570 \mathrm{~nm}$ was recorded with a Bio-Rad Smartspec Plus spectrophotometer (21). The $\mathrm{IC}_{50}$ values were then obtained by fitting the data with a Prism 3.03 program to a Sigmoidal dose-response curve.

Assay of proteasome activity. The Chemicon 20S Proteasome Activity Assay Kit was used for evaluation of proteasome activity in 4T1 and B16F10 cell lysates. Cells $(100,000)$ were plated in $35 \times 10 \mathrm{~mm}$ petri dishes and treated with various doses of Velcade $(0,0.01,0.1,1$ or $10 \mu \mathrm{M})$ for $6 \mathrm{~h}$ in the logarithmic phase of the growth. After treatment, cells were washed with $1 \mathrm{ml}$ PBS buffer and lysed in $150 \mu 1$ of ice-cold buffer [50 mM HEPES pH 7.5, 1 mM EDTA, 0.1\% NP-40, $0.002 \% \operatorname{SDS}(\mathrm{w} / \mathrm{v}), 1 \mathrm{mM} 2$-mercaptoethanol and $20 \%$ glycerol $(\mathrm{v} / \mathrm{v})]$ for $30 \mathrm{~min}$ on ice with occasional agitation. After repeated pipetting, cell lysates were centrifuged at $13,000 \mathrm{rpm}$ for $15 \mathrm{~min}$ at $4^{\circ} \mathrm{C}$. The supernatants were stored at $-80^{\circ} \mathrm{C}$ until use. A total of $10 \mu \mathrm{g}$ protein sample was added to each tube containing $25 \mathrm{mM}$ HEPES pH 7.5, $0.5 \mathrm{mM}$ EDTA, $0.05 \%$ NP-40, 0.001\% SDS and $50 \mu \mathrm{M}$ proteasome substrate LLVY-AMC specific for chymotrypsin-like activity. The total volume of cell protein, HEPES buffer and proteasome substrate amounted to $100 \mu 1$. The samples were incubated for $90 \mathrm{~min}$ at $37^{\circ} \mathrm{C}$. At the end of incubation, $2 \mathrm{ml}$ of ice-cold $\mathrm{dH}_{2} \mathrm{O}$ was added to each sample and the fluorescence was 

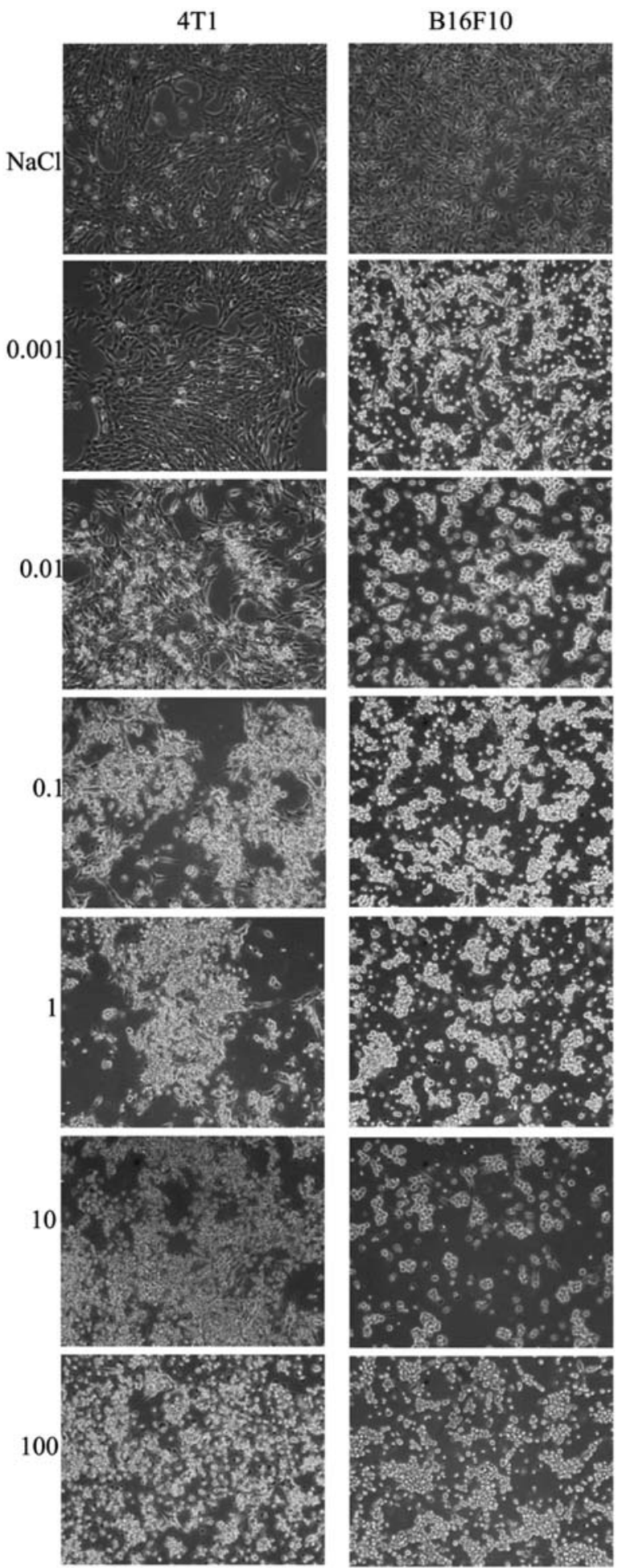

Figure 1. Analysis of cell morphology after proteasome inhibition. Cells were equally plated in sterile $35 \times 10 \mathrm{~mm}$ petri dishes and treated with various doses of Velcade $(0.001,0.01,0.1,1,10$ or $100 \mu \mathrm{M})$ or $\mathrm{NaCl}$ (vehicle) for $24 \mathrm{~h}$. After treatment, the cell morphology was visualized with an inverted microscope (magnification $\mathrm{x} 100$ ). The results are representative of at least three separate experiments.

measured using the excitation and emission filters of 380 and $460 \mathrm{~nm}$ respectively, using a Bio-Rad VersaFluor Fluorometer.

Protein determination. The protein concentration was determined using the Bio-Rad dye-binding assay. Bovine serum albumin was used as a standard (22).
Western blotting. The ECL detection system was utilized for Western blotting according to manufacturer's instructions. Proteins were separated on 10 or $12 \%$ polyacrylamide gels under denaturing conditions in $0.1 \%$ sodium dodecyl sulfate (SDS) (23). The proteins were then transferred to PVDF membrane at $70 \mathrm{~V}$ for $2 \mathrm{~h}$ at room temperature in the transfer buffer (25 mM Tris base, $192 \mathrm{mM}$ glycine, $7 \%$ methanol and $0.007 \%$ SDS). After the transfer membrane was removed, washed with methanol and left to dry for $15 \mathrm{~min}$ at room temperature to enhance the protein binding. After drying, membranes were reactivated by methanol. Reactivated membranes were then blocked with $5 \%$ skim milk overnight at $4^{\circ} \mathrm{C}$. Hsp70 level was determined by incubating the membranes with a mouse monoclonal anti-Hsp70 (1:5000 dilution) followed by HRP-conjugated anti-mouse secondary antibody (1:5000 dilution) in Tris-buffered saline-Tween-20 (TBS-T). The relative amount of p53 was determined by a rabbit polyclonal anti-p53 antibody (1:5000 dilution). p27 was detected by probing the membranes with a purified mouse monoclonal anti-p27 antibody (1:2500 dilution). The induction of p21 was detected by a mouse monoclonal anti-p21 antibody (1:500 dilution). To determine the amount of caspase- 3 , the membranes were probed with a rabbit polyclonal anticaspase-3 antibody (1:500 dilution). After ECL substrate incubation for $2 \mathrm{~min}$, the membranes were wrapped with plastic stretch and exposed to a Bio-Max X-ray film in a dark room for $1 \mathrm{~min}$ followed by manuel film developing.

Statistical analyses. Data were analyzed and graphed by GraphPad Prism 3.03 program. Where appropriate, Student t-test was used to evaluate the statistical significance. $\mathrm{P}<0.05$ was considered significant.

\section{Results}

Morphological changes in 4T1 breast cancer and B16F10 melanoma cells exposed to various concentrations of Velcade for $24 \mathrm{~h}$, were examined in detail using a light microscope. As seen in Fig. 1, cells underwent characteristic morphological changes commonly observed in apoptotic cells (24), such as shrinkage, rounding and detachment. These marked morphological changes were observed in B $16 \mathrm{~F} 10$ cells with a Velcade concentration as low as $0.001 \mu \mathrm{M}$; however, in 4T1 cells, such morphological changes were observed with $0.01 \mu \mathrm{M}$ or higher concentrations, suggesting that $\mathrm{B} 16 \mathrm{~F} 10$ cells are more sensitive to proteasome inhibitor Velcade. The anti-proliferative and cytotoxic effects of a concentration range of Velcade in both cell lines were also determined by MTT assay. As seen in Fig. 2A, in agreement with the morphological changes observed, the two cells were found differentially sensitive to Velcade-induced growth inhibition. The $\mathrm{IC}_{50}$ concentration of $\mathrm{B} 16 \mathrm{~F} 10$ was $2.5 \mathrm{nM}$ and that of $4 \mathrm{~T} 1$ was $71 \mathrm{nM}$, indicating again that B16F10 cells are highly sensitive to Velcade. The effects of various concentrations of proteasome inhibitor MG132 (a peptide aldehyde) on the viability of 4T1 breast cancer and of B16F10 melanoma cells were also determined using MTT assay. As seen in Fig. 2B, MG132 decreased cell viability in a dose-dependent manner. The $\mathrm{IC}_{50}$ of $\mathrm{MG} 132$ for $\mathrm{B} 16 \mathrm{~F} 10$ cells was $0.62 \mu \mathrm{M}$ and for $4 \mathrm{~T} 1$ was $1.22 \mu \mathrm{M}$. Together, these 
A

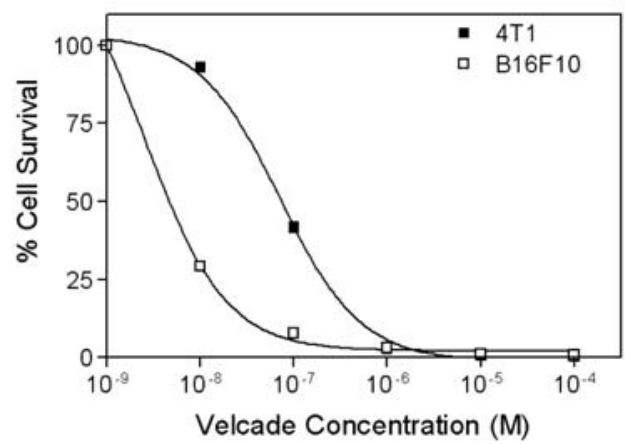

B

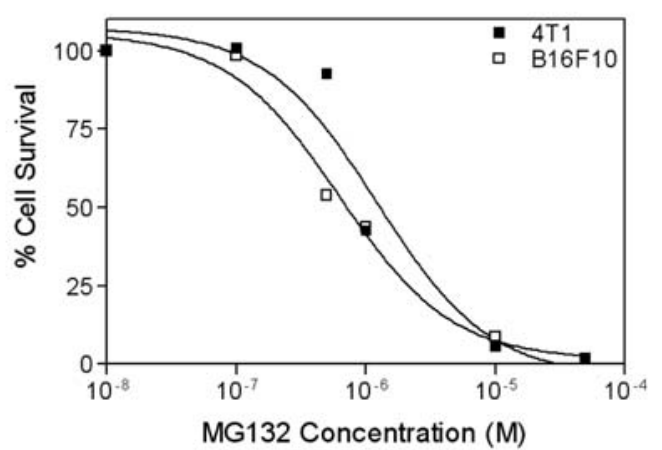

Figure 2. Growth inhibition by proteasome inhibitors in B16F10 and 4T1. (A) Effect of Velcade on cell viability. Cells were treated with 0.001,0.01, $0.1,1,10$ or $100 \mu \mathrm{M}$ for $24 \mathrm{~h}$. After the removal of the inhibitor, cells were allowed to grow for $48 \mathrm{~h}$ in fresh media without the inhibitor. After $48 \mathrm{~h}$, the number of cells surviving were determined by MTT assay as described in the Materials and methods section. (B) Effect of MG132 on cell viability. Cells were treated with $0.01,0.1,0.5,1,10$ or $50 \mu \mathrm{M} \mathrm{MG132}$ and cell survival was determined as described by MTT assay. The data points are average of two independent experiments.

data indicated that a) $\mathrm{B} 16 \mathrm{~F} 10$ cells are more sensitive to proteasome inhibition compared to $4 \mathrm{~T} 1$ cells and b) Velcade is more potent than MG132.

Initially, it was hypothesized that the mechanism of resistance to Velcade may be due to the differential activity of the proteasome in each cell line. Therefore, we measured the chymotrypsin-like proteolytic activity of the proteasome in $4 \mathrm{~T} 1$ and B $16 \mathrm{~F} 10$ cells upon treatment with various concentrations of Velcade for a short time period $(6 \mathrm{~h})$. As seen in Fig. 3, the baseline activity of the proteasome was higher by $\sim 49 \%$ in B16F10 cells than in 4T1 cells. However, treatment with $10 \mathrm{nM}$ Velcade led to 70 and $82 \%$ inhibition of proteasome activity in 4T1 and B16F10 cells, respectively. Furthermore, increasing concentrations of Velcade were equally potent in both cell lines, indicating that resistance to Velcade in 4T1 compared to B16F10 cells is not due to intrinsic differences in the sensitivity of the $26 \mathrm{~S}$ proteasome to Velcade (Fig. 3).

It has been previously reported that proteasome inhibitors preferentially induce cell death in proliferating HL60 cell, but not in quiescent, differentiated cells. Therefore, the $26 \mathrm{~S}$ proteasome appears to be required for cell survival and cell cycle progression (25). To investigate whether cell proliferation status was one of the determinants of cellular sensitivity to proteasome inhibition, the doubling time $\left(T_{d}\right)$ of each cell

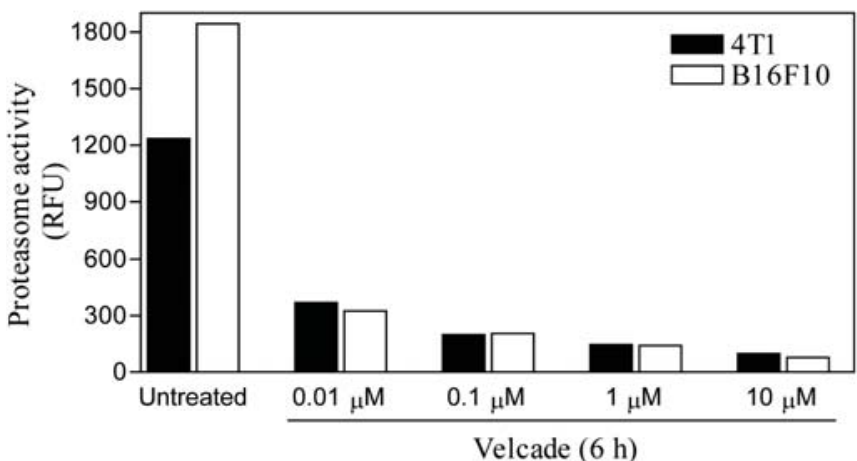

Figure 3. Assay of proteasome activity. Intracellular proteasome activity was determined after the exposure of $4 \mathrm{~T} 1$ and $\mathrm{B} 16 \mathrm{~F} 10$ cells to various doses of Velcade $(0,0.01,0.1,1$, or $10 \mu \mathrm{M})$ for $6 \mathrm{~h}$. A total of $10 \mu \mathrm{g}$ protein was used to determine the chymotrypsin-like activity of the proteasome using LLVY-AMC as a substrate. Fluorescence of the released 7-amido-4methylcoumarin dye from the substrate was measured on a Bio-Rad VersaFluor Fluorometer using a $380 \mathrm{~nm}$ excitation and a $460 \mathrm{~nm}$ emission filter. The results presented are average of two independent experiments.

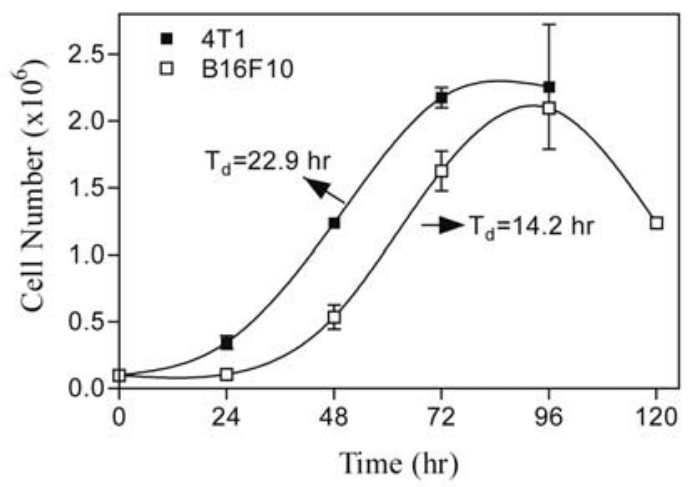

Figure 4. Growth Curve of B16F10 and 4T1 cells. Cells $(100,000)$ were seeded in $35 \times 10 \mathrm{~mm}$ dishes and cell number was then determined as a function of time using a hemacytometer after trypsinization. The results are presented as a mean \pm SEM.

was determined. As can be seen in Fig. 4, B16F10 cells are more rapidly proliferating than $4 \mathrm{~T} 1$ cells $\left(T_{d}=14.2 \mathrm{~h}\right.$ versus $T_{d}=22.9 \mathrm{~h}$ ), suggesting that the proliferative status may be an important factor in cellular sensitivity to $26 \mathrm{~S}$ proteasome inhibition.

To further examine the molecular determinants of cellular sensitivity to proteasome inhibition, the accumulation of cell cycle modulators p21, p27 and p53, and the expression of anti-apoptotic protein $\mathrm{Hsp} 70$ in $4 \mathrm{~T} 1$ and $\mathrm{B} 16 \mathrm{~F} 10$ cells were analyzed in response to proteasome inhibition using the Western blot technique. Morphological analysis of 4T1 and $\mathrm{B} 16 \mathrm{~F} 10$ cells treated with $10 \mu \mathrm{M}$ Velcade as a function of time indicated cell rounding, shrinkage and detachment as early as $8 \mathrm{~h}$ (data not shown). In addition, the proteasome activity assay indicated that almost complete inhibition of the proteasome activity was achieved in both cell lines after $6 \mathrm{~h}$ of exposure to $10 \mu \mathrm{M}$ Velcade (Fig. 3). On the basis of these experiments, it was decided to treat the cells with $10 \mu \mathrm{M}$ 


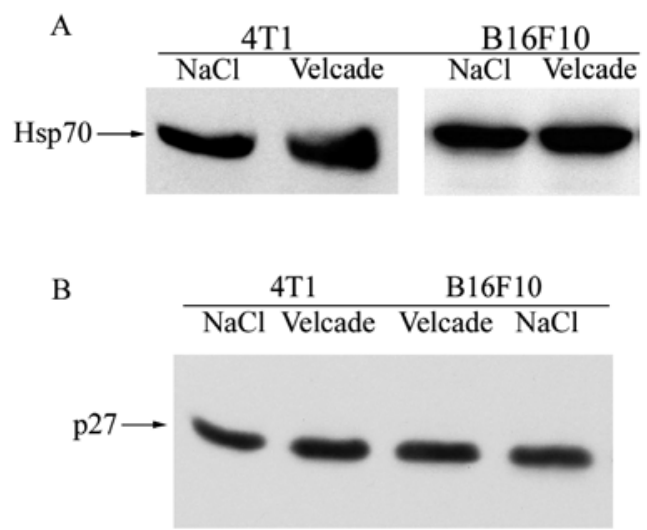

Figure 5. Western blot analysis of Hsp70 and p27. (A) To determine the level of Hsp70 after treatment with Velcade $(10 \mu \mathrm{M}$ for $6 \mathrm{~h}), 30 \mu \mathrm{g}$ total cellular protein was separated on $10 \%$ SDS-PAGE followed by Western blotting with mouse anti-Hsp70 antibody. (B) $25 \mu \mathrm{g}$ protein was separated on $12 \%$ SDS-PAGE followed by Western blotting with mouse monoclonal anti-p27 antibody. The results are representative of two independent experiments.

Velcade for $6 \mathrm{~h}$ in the subsequent experiments to compare the differences in the induction of pro-apoptotic and antiapoptotic proteins, preceeding the morphological changes observed between the two cells under investigation. The stress protein Hsp70 is known to be stimulated and has a cytoprotective role following the treatment of cells with proteasome inhibitors (26). Although a $30-40 \%$ increase in Hsp70 level was detected following the inhibition of the $26 \mathrm{~S}$ proteasome, the degree of change did not differ between two cell lines, indicating that Hsp70 is probably not involved in the differential sensitivity of B16F10 and 4T1 cells to proteasome inhibitor Velcade (Fig. 5). Then, we examined the changes in the level of cell cycle inhibitor p27 following Velcade treatment. During a short period of $26 \mathrm{~S}$ proteasome inhibition, the increase in expression level of p27 was similar in $\mathrm{B} 16 \mathrm{~F} 10$ and $4 \mathrm{~T} 1$ cell lines $(\sim 30 \%$ increase was detected), eliminating the fact that p27 determines Velcade-sensitivity in B16F10 cells (Fig. 5).

As mentioned in the Introduction, the tumor suppressor protein $\mathrm{p} 53$ is degraded by the ubiquitin-proteasome pathway in in vitro and in vivo models and is commonly known to be linked to the control of cell proliferation and cell cycle progression $(3,27)$. Stabilization of p53 leads to apoptosis in a number of cell culture models. Therefore, we examined whether there was a differential induction of p53 following a brief inhibition of the $26 \mathrm{~S}$ proteasome in both cell lines. As can be seen in Fig. 6A, treatment of B16F10 cells with $10 \mu \mathrm{M}$ Velcade for $6 \mathrm{~h}$ led to significant accumulation of $\mathrm{p} 53$

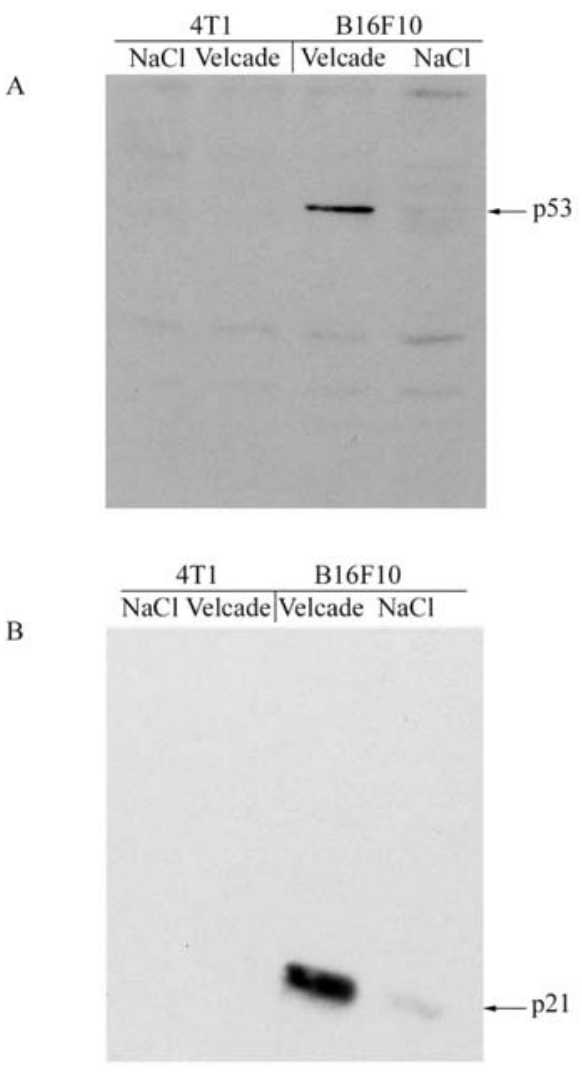

Figure 6. The effect of Velcade on p53 and p21 levels. Cells were treated with $10 \mu \mathrm{M}$ Velcade for $6 \mathrm{~h}$. Then $30 \mu \mathrm{g}$ total cellular protein was separated on $12 \%$ SDS-PAGE. The accumulation of p53 (A) or p21 (B) was detected using Western blot analysis. The results are representative of two independent experiments.

protein compared to vehicle-treated $(\mathrm{NaCl})$ cells. In contrast, Velcade-treatment did not result in accumulation of p53 in $4 \mathrm{~T} 1$ cells. The tumor suppressor protein p53 is a transcriptional factor that induces the expression of the cyclindependent kinase inhibitor p21. To determine whether p53 accumulation in $\mathrm{B} 16 \mathrm{~F} 10$ in response to proteasome inhibition was functional, p21 expression after Velcade treatment was assayed in both cell lines. Similarly, a brief treatment with Velcade induced a very significant accumulation of p21 in B16F10 cells but not in 4T1 cells (Fig. 6B). Although there is contrasting evidence regarding the presence of p53 in $4 \mathrm{~T} 1$ cells $(28,29)$, the results here show that this mammary cell line is most likely a p53-null cell. Collectively, these results indicated that inhibition of the chymotrysin-like activity of the $26 \mathrm{~S}$ proteasome by Velcade resulted not only in stabilization of p53 but also remarkable induction of p21 in

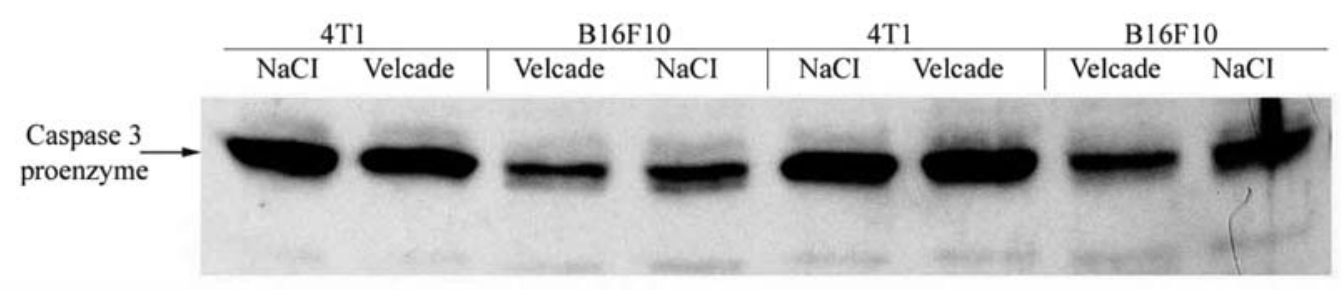

Figure 7. Western blot analysis of caspase-3. To determine the level of caspase-3 proenzyme after treatment with Velcade (10 $\mu \mathrm{M}$ for $6 \mathrm{~h}), 25 \mu \mathrm{g}$ total cellular protein was separated on $12 \%$ SDS-PAGE followed by Western blotting with rabbit polyclonal anti-caspase- 3 antibody. The results are representative of two independent experiments, each run in duplicates. 
B16F10 cells. While the signaling cascade induced by $\mathrm{p} 53$ during apoptosis depends on the cell type used, it is well documented that p53-induced apoptosis is commonly mediated by pro-apoptotic proteins Bax, Bad and PUMA, which are essential proteins for the release of cytochrome $\mathrm{c}$ from the mitochondrial membrane and subsequent activation of caspase-3 (30,31). Caspase-3 is an enzyme activated in almost every apoptotic process (32) and is therefore considered a hallmark of apoptosis activation. Therefore, we examined whether the proenzyme form of this apoptosis executioner is cleaved in response to proteasomal inhibition by Velcade. As can be seen in Fig. 7, we observed a significant $20 \%$ reduction in the proenzyme form of caspase- 3 upon inhibition of the $26 \mathrm{~S}$ proteasome by Velcade in $6 \mathrm{~h}$ $(p=0.0117)$. However, no change was detected in caspase- 3 level in 4T1 cells, suggesting that the sensitivity of B16F10 cells is probably associated with caspase- 3 mediated apoptosis induction following p53 and p21 accumulation after inhibition of the $26 \mathrm{~S}$ proteasome.

\section{Discussion}

In this study, the differential effects of proteasome inhibitors on the viability of B16F10 melanoma and 4T1 cancer cells were examined. B16F10 melanoma cells originate from C57BL-6 mice, form large tumors in vivo and are used commonly as an in vivo melanoma model (33). 4T1 breast carcinoma cells are also widely used as a metastatic mammary tumor model (34). The findings presented in this study demonstrate for the first time that B16F10 melanoma cells are more sensitive towards proteasomal inhibition than 4T1 cells as determined by morhophological analysis and MTT assay. It was found that proteasome inhibitor Velcade is more potent and cytotoxic than proteasome inhibitor MG132 in both cell lines tested. Although the basal level of the proteasome activity was higher in B16F10 cells compared to 4T1 cells, both cell lines showed marked inhibition of the $26 \mathrm{~S}$ proteasome upon exposure to various doses of Velcade, eliminating the potential differences in the proteasomeinhibition as the determinant of the Velcade-resistance. Using a number of mantle cell lymhoma (MCL) cell lines, Rizzatti et al also concluded that the intrinsic resistance to Velcade is not due to the basal activity of the $26 \mathrm{~S}$ proteasome or compensatory increases in the proteasome activity after drug exposure (35). It was previously shown that $26 \mathrm{~S}$ proteasome inhibition is pro-apoptotic in rapidly dividing HL60 leukemic and endothelial cells $(25,36)$. Similarly, Lopes et al reported that proteasome inhibitor MG115 failed to induce apoptosis of quiescent Rat- 1 cells. In contrast, the proteasome inhibitor tested in their study was still able to induce the apoptosis of non-proliferating differentiated PC12 cells and they concluded that cell proliferation was not the sole determinant of sensitivity to proteasomal inhibition (27). The results presented herein support the fact that there is a correlation between the cellular sensitivity to proteasome inhibitors and rapid proliferation rate since B16F10 cells are rapidly dividing and are more sensitive to Velcade as compared to $4 \mathrm{~T} 1$ cells.

The present study indicates that the cellular sensitivity or resistance of cells examined here toward proteasomal inhibition, may not result from the differences in the accumulation of anti-apoptotic protein $\mathrm{Hsp} 70$ or Cdkinhibitor $\mathrm{p} 27$. In agreement with these results, expression of Hsp70 was found to be similar in Velcade-sensitive cell line SW1573 and in resistant cell line H460 (both are NSCLC cells). In contrast, the expression of anti-apoptotic proteins Hsp27 and Hsp90 were higher in SW1573 cells than in H460 cells. The author concluded that the apoptosis resistance of SW1573 cells may result from increased expression of Hsp27 (15). Chauhan et al also reported that Hsp27 confers Velcaderesistance in lymphoma cells (20). It is therefore of interest to determine the expression level of Hsp27 as well as Hsp90 in B16F10 and 4T1 cells upon exposure to proteasome inhibitors.

Remarkable increases in tumor suppressor p53 level and cell cycle inhibitor p21 observed very early (in $6 \mathrm{~h}$ ) after the addition of Velcade, clearly suggest that p53 and the p53inducible gene product $\mathrm{p} 21$ are important factors in B16F10 cellular sensitivity toward proteasomal inhibition. In addition, we observed a statistically significant $20 \%$ decrease in caspase- 3 proenzyme in $\mathrm{B} 16 \mathrm{~F} 10$ but no apparent changes in $4 \mathrm{~T} 1$ cells. The reduction in caspase- 3 may thus be stimulated by p53-induced pro-apoptotic protein (e.g., Bax) and through subsequent release of cytochrome $\mathrm{c}$ from mitochondria in B16F10 cells. Nevertheless, it is known that $26 \mathrm{~S}$ proteasome inhibition induces growth inhibition or apoptosis in a p53-independent manner $(37,38)$. Therefore, the growth inhibition observed in 4T1 cells may be mediated through a p53-independent mechanism since the results presented here and in a prior study (28) prove that $4 \mathrm{~T} 1$ cells are p53-null cells. In future studies we will design experiments to further investigate the mechanism of growth inhibition in $4 \mathrm{~T} 1$ cells to delineate further the intracellular functions of the $26 \mathrm{~S}$ proteasome.

A better understanding of the molecular link between cellular proliferation, apoptosis and $26 \mathrm{~S}$ proteasome is crucial for understanding the differences between Velcaderesponsive and non-responsive patients in multiple myeloma and possibly other cancer patients. Further experiments will certainly help to define novel molecular targets and therapeutic strategies to overcome the clinical resistance to proteasome inhibition in some cancer patients.

\section{Acknowledgements}

This work was funded by the Scientific and Technological Research Council of Turkey (TUBITAK) with Project No $105 \mathrm{~S} 351$ to A. Yerlikaya. The study was supported in part by funds from Akdeniz University Research Units, Antalya, Turkey. We would like to thank graduate student Harun Dokudur (Dumlupinar University, Department of Biology) for assistance with experiments carried out in this study.

\section{References}

1. Hilt $\mathrm{W}$ and Wolf DH: Proteasomes: destruction as a programme. Trends Biochem Sci 21: 96-102, 1996.

2. Yerlikaya A: Cellular functions of the $26 \mathrm{~S}$ proteasome. Turk J Biol 28: 31-38, 2004.

3. Hershko A and Ciechanover A: The ubiquitin system. Annu Rev Biochem 67: 425-479, 1998. 
4. Voges D, Zwickl P and Baumeister W: The 26S proteasome: a molecular machine designed for controlled proteolysis. Annu Rev Biochem 68: 1015-1068, 1999.

5. Murakami Y, Matsufuji S, Kameji T, et al: Ornithine decarboxylase is degraded by the $26 \mathrm{~S}$ proteasome without ubiquitination. Nature 360: 597-599, 1992.

6. Pagano M: Cell cycle regulation by the ubiquitin pathway. FASEB J 11: 1067-1075, 1997.

7. He H, Qi XM, Grossmann J and Distelhorst CW: c-Fos degradation by the proteasome. An early, Bcl-2-regulated step in apoptosis. J Biol Chem 273: 25015-25019, 1998.

8. Yerlikaya A and Stanley BA: S-adenosylmethionine decarboxylase degradation by the $26 \mathrm{~S}$ proteasome is accelerated by substrate-mediated transamination. J Biol Chem 279: 12469-12478, 2004.

9. Chau V, Tobias JW, Bachmair A, et al: A multiubiquitin chain is confined to specific lysine in a targeted short-lived protein. Science 243: 1576-1583, 1989.

10. Jentsch S: The ubiquitin-conjugation system. Annu Rev Genet 26: 179-207, 1992.

11. Hershko A, Ciechanover A, Heller H, Haas AL and Rose IA: Proposed role of ATP in protein breakdown: conjugation of protein with multiple chains of the polypeptide of ATPdependent proteolysis. Proc Natl Acad Sci USA 77: 1783-1786, 1980.

12. Adams J: The development of proteasome inhibitors as anticancer drugs. Cancer Cell 5: 417-421, 2004.

13. Cardoso F, Durbecq V, Laes JF, et al: Bortezomib (PS-341, Velcade) increases the efficacy of trastuzumab (Herceptin) in HER-2-positive breast cancer cells in a synergistic manner. Mol Cancer Ther 5: 3042-3051, 2006.

14. Chauhan D, Hideshima T, Mitsiades C, Richardson P and Anderson KC: Proteasome inhibitor therapy in multiple myeloma. Mol Cancer Ther 4: 686-692, 2005.

15. Voortman J, Checinska A and Giaccone G: The proteasomal and apoptotic phenotype determine bortezomib sensitivity of non-small cell lung cancer cells. Mol Cancer 6: 73, 2007.

16. Burger AM and Seth AK: The ubiquitin-mediated protein degradation pathway in cancer: therapeutic implications. Eur J Cancer 40: 2217-2229, 2004.

17. Markovic SN, Geyer SM, Dawkins F, et al: A phase II study of bortezomib in the treatment of metastatic malignant melanoma. Cancer 103: 2584-2589, 2005.

18. Teicher BA, Ara G, Herbst R, Palombella VJ and Adams J: The proteasome inhibitor PS-341 in cancer therapy. Clin Cancer Res 5: 2638-2645, 1999.

19. Fuchs D, Berges C, Opelz G, Daniel V and Naujokat C: Increased expression and altered subunit composition of proteasomes induced by continuous proteasome inhibition establish apoptosis resistance and hyperproliferation of Burkitt lymphoma cells. J Cell Biochem 103: 270-283, 2008.

20. Chauhan D, Li G, Shringarpure R, et al: Blockade of Hsp27 overcomes Bortezomib/proteasome inhibitor PS-341 resistance in lymphoma cells. Cancer Res 63: 6174-6177, 2003.

21. Freshney RI: Cytotoxicity. In: Culture of animal cells: a manual of basic techniques, John Wiley \& Sons, Inc., New Jersey, pp 359-373, 2005.

22. Bradford MM: A rapid and sensitive method for the quantitation of microgram quantities of protein utilizing the principle of protein-dye binding. Anal Biochem 72: 248-254, 1976.
23. Laemmli UK: Cleavage of structural proteins during the assembly of the head of bacteriophage T4. Nature 227: 680-685, 1970 .

24. Zhang QY, Jiang M, Zhao CQ, et al: Apoptosis induced by one new podophyllotoxin glucoside in human carcinoma cells. Toxicology 212: 46-53, 2005.

25. Drexler HC: Activation of the cell death program by inhibition of proteasome function. Proc Natl Acad Sci USA 94: 855-860, 1997.

26. Robertson JD, Datta K, Biswal SS and Kehrer JP: Heat-shock protein 70 antisense oligomers enhance proteasome inhibitorinduced apoptosis. Biochem J 344: 477-485, 1999.

27. Lopes UG, Erhardt P, Yao R and Cooper GM: p53-dependent induction of apoptosis by proteasome inhibitors. J Biol Chem 272: 12893-12896, 1997.

28. Wang H, Mohammad RM, Werdell J and Shekhar PV: p53 and protein kinase $\mathrm{C}$ independent induction of growth arrest and apoptosis by bryostatin 1 in a highly metastatic mammary epithelial cell line: In vitro versus in vivo activity. Int $\mathrm{J}$ Mol Med 1: 915-923, 1998.

29. Shi SQ, Xu L, Zhao G, Yang Y and Peng JP: Apoptosis and tumor inhibition induced by human chorionic gonadotropin beta in mouse breast carcinoma. J Mol Med 84: 933-941, 2006.

30. Ding WX, Ni HM, Chen X, Yu J, Zhang L and Yin XM: A coordinated action of Bax, PUMA, and p53 promotes MG132induced mitochondria activation and apoptosis in colon cancer cells. Mol Cancer Ther 6: 1062-1069, 2007.

31. Cregan SP, MacLaurin JG, Craig CG, et al: Bax-dependent caspase- 3 activation is a key determinant in p53-induced apoptosis in neurons. J Neurosci 19: 7860-7869, 1999.

32. Pasquini LA, Besio Moreno M, Adamo AM, Pasquini JM and Soto EF: Lactacystin, a specific inhibitor of the proteasome, induces apoptosis and activates caspase- 3 in cultured cerebellar granule cells. J Neurosci Res 59: 601-611, 2000.

33. Amoh Y, Li L, Yang M, et al: Hair follicle-derived blood vessels vascularize tumors in skin and are inhibited by Doxorubicin. Cancer Res 65: 2337-2343, 2005.

34. Erin N, Zhao W, Bylander J, Chase G and Clawson G: Capsaicin-induced inactivation of sensory neurons promotes a more aggressive gene expression phenotype in breast cancer cells. Breast Cancer Res Treat 99: 351-364, 2006.

35. Rizzatti EG, Mora-Jensen H, Weniger MA, et al: Noxa mediates bortezomib induced apoptosis in both sensitive and intrinsically resistant mantle cell lymphoma cells and this effect is independent of constitutive activity of the AKT and NFkappaB pathways. Leuk Lymphoma 49: 798-808, 2008.

36. Drexler HC, Risau W and Konerding MA: Inhibition of proteasome function induces programmed cell death in proliferating endothelial cells. FASEB J 14: 65-77, 2000.

37. Wagenknecht B, Hermisson M, Eitel K and Weller M: Proteasome inhibitors induce p53/p21-independent apoptosis in human glioma cells. Cell Physiol Biochem 9: 117-125, 1999.

38. Harris GFT, Anderson ME and Lee JH: The effect of proteasome inhibition on p53 degradation and proliferation in tonsil epithelial cells. Arch Otolaryngol Head Neck Surg 134: 157-163, 2008. 